\title{
LABOUR MARKET IN SERBIA - AN OPPORTUNITY OR LIMITATION OF ECONOMIC GROWTH
}

\author{
Aleksandra Tesić1, Vladimir Iić2 ${ }^{2}$ Anastazija Tanja Djelić3
}

\begin{abstract}
Summary
This raises the question of why some countries based their economic power to human resources, the knowledge economy and large investments in science, while others see their citizens primarily as a social category which requires the cost of education, medical treatment, social protection, salaries and pensions? The answer lies in the concept of social development, that is, whether investing in people is considered as an investment or cost. The Company's investment in human resources, education and science, the investments are those companies that are leaders of development and their economies recorded the highest growth rates in recent history. Opposite them are the companies that have not yet recognized the importance of education and investment in people as the most important resource and a factor of development. Such companies are on the margins of development, marginalized and occupied "internal" problems, unaware that standing in the village, in the context of economic growth, the reverse. Serbia at this moment belongs, unfortunately, this second group of countries that do not understand the full meaning and significance of human potential. Under certain conditions, it is possible to reverse the existing concept and establish an open and developed labor market that will be the engine of development and a key factor of economic growth in Serbia.
\end{abstract}

Key words: labor market, economic growth, education, jobs, employment

JEL: J60, Q10

\section{Introduction}

The labor market in Serbia in the political, social, and even economic analysis considers mainly through the prism of social context, the problem of unemployment and the load with which it must deal the most responsible in the country. Few people in the labor

1 Aleksandra Tesic Ph.D., Associate Professor, Fakultet za Ekonomiju i Inženjerski Menadžment u Novom Sadu, Novi Sad, Serbia, Phone: +381 6920009 54, E-mail: prof.aleksandra.tesic@gmail.com

2 Vladimir Ilic, Ph.D., Assistant Professor, Visoka škola za poslovnu ekonomiju i preduzetništvo, Belgrade, Serbia, Phone: +381 6487877 95, E-mail: vlada191@gmail.com

3 Anastazija Tanja Djelic, Načelnik resora za poreze i akcize ministarstva finansija, Belgrade, Serbia, Phone: +381 63295 656, E-mail: tanja.djelic@gmail.com

EP 2015 (62) 4 (1117-1136) 
market and its development, see opportunities and potential for economic growth. This is largely justified because in our reality there is almost no labor market in the full sense of the term. As a relatively small country, Serbia, due to a number of different circumstances did not develop the labor market - it is shallow, underdeveloped, followed by low labor mobility, devastated transition downturn in conditions of political instability, wars and economic sanctions. Bad circumstances in the environment are supplemented by internal failures in the education system, the disastrous privatization and polarization (politicization) of the public sector in the field of employment. Mass recruitment and hiring party (incompetent and unskilled) personnel throughout the public administration and public enterprises both at the national and at the local level, entirely undermines the idea of any free labor market. That terrible pressure on public sector employment has led to the paradox that the average wage in the private sector are significantly lower, position and safety of employees getting worse, a swollen administration ever greater burden of the already powerless Serbian economy.

Above all, for decades what has been completely missing is a clear link between the needs of employers for labor and an education system that now sees no need, is not respected and ignored. Therefore, in the present moment, there are no key assumptions for the establishment of market economy in the segment of the need to work and supply of labor. The needs of employers and the labor supply is, to a large extent, they do not match or there are clear indications that the "labor market" -offsets those needs. Another problem is poor demographic trends in terms of a dramatic decline of the birth rate, an aging population, the exodus of young people to foreign countries and an unprecedented concentration of population in large cities, particularly Belgrade. It is clear that in these circumstances the labor market can hardly be a function of economic growth and development.

On the other hand, many countries of the world are in the labor force and the labor market based their development, primarily the so-called. Asian Tigers (Taiwan, South Korea, Hong Kong, Singapore), also Japan, China and, of course, the most countries of Europe, USA, Australia and others. What is common to all these countries are large investments in education and adapting competences and knowledge workers to the real needs of the labor market and employers. This is the key formula that all these countries enabled stable and sustainable growth over a long period of time with high growth rates. Many of these countries are active "importers" of labor, particularly those of professional and highly educated (most notably the United States that have the best educational system in the world, while not asking for the cost of experts "imported" from around the world), which guarantees economic development.

In order Serbia turned his weakness into an opportunity, and that the labor market becomes a factor of development, and not as a limitation, it is necessary to follow the examples of success. They have enough, and all have in common that they have invested in education (Serbia invests many times less in education than in the developed countries). It is understood that a parallel must work on creating business environment that will improve the competitive position of Serbia in the last five or six years oscillates 
in the global rankings of competitiveness about 95 seats out of 145 countries. On this list, Serbia is in the company of Kenia, Tajikistan, Mongolia, Honduras, Nicaragua, Cambodia and others. The only European country in this group apart from Serbia Albania. This position says that Serbia needs structural reforms, institution building, infrastructure, new technology, the establishment of the capital market and the labor market. It sounds paradoxical, but about a series of errors and omissions in education, economic policy, privatization of Serbia has both excess and shortage of labor. Despite around 750,000 unemployed registered with the National Employment Service, many jobs remain unfilled for years. Due to the poor structure of unemployed persons observed through different aspects (age, educational profile, gender, work experience, etc.) Even if (hypothetically) during a month in Serbia opened 750,000 jobs employment would, in these circumstances, found barely third of the unemployed. So, in that situation would have to "import" half a million workers (?!). Why is this so, the answer should be found later in this paper.

\section{Economic indicators in Serbia and the problems of the previous development}

Serbia is like the entire world, seriously shaken by global economic crisis whose end is several times announced, but is now seven years after the outbreak of the crisis clearly that the long-awaited end is not in sight. It is no longer the point of crisis only in poor economic indicators, the possibility of bankruptcy of entire countries, rising unemployment and a simple decline in living standards. On the basis of the latest crisis lies primarily unsustainability of the world economic order, which for decades increased the gap between rich and poor. Therefore, a multitude of social, political, geostrategic, religious and other factors is incorporated in the latest economic crisis of the globalized world. Liberalism as a concept and a key mantra of globalization has been left out today and his fiercest advocates and theoreticians are faced with the realities of the modern world and threats such as catastrophic climate change, resource constraints, potential regional (and expanding) armed conflicts, migration and migration of eastern peoples westward. The current crisis in Syria and the wave of refugees from that part of the world to Europe is only an announcement of "the great migration" to what will surely come if it does not abandon the current model of global economic order (Chmieliński, 2013).

Serbia is the last country in Europe where the transition is still ongoing. Collapsed economic structure from the communist period, which existed in a closed economy and in the former Yugoslavia, should be replaced by a new, more flexible structure which will optimally exploit the potential of Serbia and ensure steady economic growth. Do you go in the direction of development of the industry or agriculture is a secondary issue in relation to the need to create a business environment that will allow businesses that, in accordance with their interests, activate dormant and inactive resources Serbia (Vojnović et al., 2014). In creating this environment we have not had too much success, and the post-crisis period is a new chance and therefore it is necessary to do jobs that will benefit the economy and citizens. The economic crisis has brought into question many of valid doctrine and approach to the crisis is moving from whether to save or increase spending, to whether they should intervene in the direction of help heavily 
indebted countries and to rehabilitate the banking sector or not.

Economically sustainable development of Serbia in the long run is not possible at the current way the GDP growth based on domestic demand growth caused by foreign loans and privatization revenues. The consequence of this growth is a constant deficit of foreign trade balance, wage growth above productivity growth and ongoing inflationary pressures. In the current concept of development more than 4/5 of the capital inflow of loans and foreign direct investment went toward unshared sectors (banking, trade, real estate, transport, telecommunications), while the exchange-sectors (industry, mining, agriculture) that only they can improved the trade imbalance remained only $1 / 5$ of the capital. This situation is untenable especially because we can no longer count on revenues from privatization and additional borrowing. This period has been completed and have left us but to reforms in all areas attract foreign direct investment in the aforementioned exchange-sectors and activate the domestic capital in this direction (Stojadinović-Jovanović, Dašić, 2015).

Table 1. Key macroeconomic indicators Serbia 2008-2015.

\begin{tabular}{|c|c|c|c|c|c|c|c|c|}
\hline & 2008 & 2009 & 2010 & 2011 & 2012 & 2013 & 2014 & 2015 \\
\hline $\begin{array}{l}\text { Gross domestic } \\
\text { product mil euro }\end{array}$ & $33,704.5$ & $30,654.7$ & $29,766.3$ & $33,423.8$ & $31,683.1$ & $34.262,9$ & $33.059,1$ & $33.008,3$ \\
\hline $\begin{array}{l}\text { Gross domestic } \\
\text { product, per capita, } \\
\text { in euro }\end{array}$ & $4,585.5$ & $4,187.3$ & $4,082.4$ & $4,620.4$ & $4,401.0$ & 4.783 & & \\
\hline \begin{tabular}{|l|} 
Gross domestic \\
product, real growth, \\
in $\% 1$
\end{tabular} & 5.4 & -3.1 & 0.6 & 1.4 & -1.0 & 2,6 & $-1,8$ & 0,5 \\
\hline $\begin{array}{l}\text { Prices and the } \\
\text { expences of life, } \\
\text { growth rate }\end{array}$ & & & & & & & & $\begin{array}{r}\text { January- } \\
\text { April }\end{array}$ \\
\hline $\begin{array}{l}\text { Consumer price, the } \\
\text { end of period }\end{array}$ & 8.6 & 6.6 & 10.3 & 7.0 & 12.2 & 2.2 & 1.7 & 1.9 \\
\hline $\begin{array}{l}\text { Foreign economic } \\
\text { exchange, in mil. } \\
\text { euro } 0^{4,5,6}\end{array}$ & & & & & & & & $\begin{array}{r}\text { January- } \\
\text { April }\end{array}$ \\
\hline \begin{tabular}{|l} 
Goods export \\
\end{tabular} & $7,428.8$ & $5,961.3$ & $7,393.4$ & $8,441.4$ & $8,738.9$ & $10,996.7$ & $11,157.0$ & $3,783.6$ \\
\hline Goods export, \% & 15.5 & -19.8 & 24.0 & 14.2 & 3.5 & 25.8 & 1.4 & 4.2 \\
\hline Goods import & $16,283.0$ & $11,327.0$ & $12,423.5$ & $14,250.0$ & $14,716.7$ & $15,469.0$ & $15,526.3$ & $5,225.2$ \\
\hline Goods import, $\%$ & 17.9 & -30.4 & 9.7 & 14.7 & 3.3 & 5.1 & 0.4 & 6.2 \\
\hline $\begin{array}{l}\text { The deficit of the } \\
\text { goods exchange }\end{array}$ & $-8,854.2$ & $-5,365.7$ & $-5,030.1$ & $-5,808.6$ & $-5,977.9$ & $-4,472.3$ & $-4,369.2$ & $-1,441.6$ \\
\hline $\begin{array}{l}\text { Balance of } \\
\text { payments, in mil. } \\
\text { Euro }\end{array}$ & & & & & & & & $\begin{array}{r}\text { January- } \\
\text { March }\end{array}$ \\
\hline $\begin{array}{l}\text { The deficit of the } \\
\text { current transactions } \\
\text { (BPM6) })^{5,8}\end{array}$ & $-7,126.3$ & $-2,031.8$ & $-2,036.7$ & $-3,656.0$ & $-3,671.4$ & $-2,098.3$ & $-1,984.7$ & -449.8 \\
\hline $\begin{array}{l}\text { The deficit of the } \\
\text { current transactions, } \\
\% \text { GDP }\end{array}$ & -21.1 & -6.6 & -6.8 & -10.9 & -11.6 & -6.1 & -6.0 & \\
\hline
\end{tabular}




\begin{tabular}{|c|c|c|c|c|c|c|c|c|}
\hline & 2008 & 2009 & 2010 & 2011 & 2012 & 2013 & 2014 & 2015 \\
\hline $\begin{array}{l}\text { The deficit of the } \\
\text { current transactions } \\
\text { (BPM6) }\end{array}$ & $-7,126.3$ & $-2,031.8$ & $-2,036.7$ & $-3,656.0$ & $-3,671.4$ & $-2,098.3$ & $-1,984.7$ & -449.8 \\
\hline $\begin{array}{l}\text { The deficit of the } \\
\text { current transactions, } \\
\% \text { GDP }\end{array}$ & -21.1 & -6.6 & -6.8 & -10.9 & -11.6 & -6.1 & -6.0 & \\
\hline $\begin{array}{l}\text { Foreign direct } \\
\text { investments, net, in } \\
\text { mil. Euro } 5 \text {,8 }\end{array}$ & $2,485.7$ & $2,067.8$ & $1,133.4$ & $3,319.6$ & 752.8 & $1,298.1$ & $1,236.3$ & 235.3 \\
\hline \begin{tabular}{|l|} 
Monetary and \\
foreign exchange \\
indicators, the end of \\
period
\end{tabular} & & & & & & & & $\begin{array}{r}\text { January- } \\
\text { April }\end{array}$ \\
\hline $\begin{array}{l}\text { Foreign exchange } \\
\text { reserves PBS, mil. } \\
\text { Euro }\end{array}$ & 8,162 & 10,602 & 10,002 & 12,058 & 10,915 & 11,189 & 9,907 & 10,534 \\
\hline $\begin{array}{l}\text { The value of US } \\
\text { dollar in regards to } \\
\text { dinar, The average } \\
\text { period }\end{array}$ & 55.76 & 67.47 & 77.91 & 73.34 & 88.12 & 85.17 & 88.54 & 108.92 \\
\hline $\begin{array}{l}\text { The value of euro in } \\
\text { regards to dinar, the } \\
\text { average period }\end{array}$ & 81.44 & 93.95 & 103.04 & 101.95 & 113.13 & 113.14 & 117.31 & 121.16 \\
\hline $\begin{array}{l}\text { Foreign currency } \\
\text { savings of the } \\
\text { population in mil. } \\
\text { euro }\end{array}$ & 4,775 & 6,014 & 7,106 & 7,611 & 8,272 & 8,418 & 8,525 & 8,639 \\
\hline $\begin{array}{l}\text { Employment, wages } \\
\text { and pensions }\end{array}$ & & & & & & & & $\begin{array}{r}\text { January- } \\
\text { April } \\
\end{array}$ \\
\hline $\begin{array}{l}\text { No of employees, } \\
\text { average, in } 000\end{array}$ & 1,999 & 1,889 & 1,796 & 1,746 & 1,727 & 1,715 & 1,698 & 1,697 \\
\hline $\begin{array}{l}\text { Actively unemployed } \\
\text { persons, average, } \\
\text { in } 000\end{array}$ & 756 & 747 & 744 & 753 & 762 & 775 & 767 & 761 \\
\hline $\begin{array}{l}\text { Unemployment rate, } \\
\text { MOP }\end{array}$ & 13.6 & 16.1 & 19.2 & 23.0 & 23,9 & 22,1 & 18,9 & 19,2 \\
\hline $\begin{array}{l}\text { Net wage, average } \\
\text { period, in dinar }\end{array}$ & 32,746 & 31,733 & 34,142 & 37,976 & 41,377 & 43,932 & 44,530 & 42,714 \\
\hline - real growth rate & 3.9 & \begin{tabular}{l|l|}
0.2 & \\
\end{tabular} & 0.7 & 0.2 & 1.1 & -1.5 & -1.5 & -1.4 \\
\hline $\begin{array}{l}\text { Average pension, } \\
\text { average period in } \\
\text { dinars }\end{array}$ & 17,660 & 19,788 & 19,890 & 21,285 & 22,450 & 23,378 & 23,553 & 22,722 \\
\hline - real growth rate & \begin{tabular}{ll|}
14.3 \\
\end{tabular} & \begin{tabular}{ll|}
3.3 \\
\end{tabular} & -5.9 & \begin{tabular}{ll|}
-3.6 \\
\end{tabular} & -2.2 & -3.4 & -2.1 & -5.0 \\
\hline
\end{tabular}

Source: Republican bureau for statistics, 2014; (http://webrzs.stat.gov.rs/WebSite/Public/ PageView.aspx?pKey=1) 
If even a cursory look at the data from the review in Table 1, the first conclusion is stagnation in some areas slightly declining in some slight recovery. All in all, not enough to catch up those who are twenty and thirty years ahead of us. Therefore, Serbia is still relatively lagging behind and is quite far from being able to even closer to some of us for decades looked to the back like so many countries. "Eastern bloc". Catching up with the most developed countries of Europe has a realistic plan for the second half of the 21 century. After-crisis year 2008 until today, it is clear that Serbia simply not coped in such circumstances and that so far stalled. The moves of the new government, especially its rhetoric correlate with what should be the goal and the path, but we should wait for the results.

Gross domestic product in 2015 will not reach the 2008 year will be slightly below the strongest evidence of stagnation and lagging behind Serbia. In the reporting period we are in 2009, 2012 and 2014 recorded a negative growth rate of GDP $(-3.1 \%,-1.0 \%$ and $-1.8 \%$ ). In 2015 we will despite the negative forecasts by the IMF and the World Bank (-0.5\%) manage to blow up the GDP by 0.5 to $1 \%$. From the table 1 we can see a clear correlation mentioned negative rate and the inflow of foreign direct investment (FDI). Namely, in the aforementioned years falling GDP there was also a significant drop in FDI. So, one of the most important factors of growth of Serbia in the entire period, absent or decreased (with around 2.5 billion. In 2008 to $\$ 1.2$ billion. \$ In 2014). Forecast for 2015 is also bleak - only about a billion dollars of FDI. This slowed the inflow of foreign investments is the consequence of the global crisis but, on the other side, and the consequences leftover of reforms and creating a healthy business environment. Unreformed public sector in Serbia is becoming a huge burden and stone around the neck and on the state budget and for economic growth. The losses of the public sector redundancies, over-indebtedness of public enterprises, the party managing and unwillingness to change them would hamper any effort towards development. Reforms that a whole decade, and announce in many areas does not happen. All laws adopted by the National Assembly of RS from 2000 to date were "reform." A reform of the no sign. This just confirms the unwillingness of society as a whole to make a break with the past and accept the standards that apply in our immediate neighborhood - EU, which is so "dedicated to" strive for.

In the reporting period had a relative price stability, so that we during 2013 and 2014, fully steady inflation. Unfortunately, this good result is the consequence of the dominant - domestic demands due to real wage cuts, which in those years recorded negative rates. Although this trend has a negative effect on the standard of the citizens of Serbia, it is a good circumstance to us increasing wages above productivity growth as soon as a regular case. When it comes to the export of good news is that it grows in the reporting period (with the exception of the crisis year 2009), especially after reaching full production of Fiat's plant in Kragujevac, in 2012. Therefore, we have achieved a significant deceleration and decline in foreign trade deficit, which will be reflected in the monetary sphere. Foreign currency reserves of Serbia during these eight years have a certain stability and oscillate around 10 billion. Euros, while deposits in banks 
recorded a slight increase and is currently at about 8.5 billion Euros. These indicators can guarantee a respectable level of liquidity Serbia but in terms of the needs of growth and development are insufficient to significantly accelerate the economy (StojadinovićJovanović, Dašić, 2015).

At the end of the analysis of macroeconomic indicators Serbia will look to the data on employment and earnings that are most important to citizens and their families. During this period, the number of those who reported to work has been reduced by over 300,000 (with \$ 2 million in 2008 to 1.7 million in 2015). It is exactly $15 \%$ fewer employees. The number of persons registered with the National Employment Service throughout the entire period was about 750,000 job seekers. The unemployment rate according to the Labor Force Survey from $13.6 \%$ in 2008 grew to $23 \%$ in 2011, that in 2015 decreased to $19.2 \%$. What happened to those 300,000 fewer employees if the records of the National we have 750,000 unemployed stable and relatively significant fluctuations in the unemployment rate? At this point we can only assume (not perform the correct conclusion) that is part of the staff left Serbia, part went to the informal economy, part (unfortunately) lost in the negative natural increase, and a part of the former unemployed, discouraged stepped forward with "labor market" (Kuzman, et. al., 2013). Below we will explain in detail these paradoxes and trends when it comes to labor force in Serbia. When it comes to pensions noticeable is their constant real decline after anything reasonable growth in 2008 (except for political reasons, others did not) of $14 \%$. It is similar with real earnings that after admittedly modest 2008 growth of $3.9 \%$ (only the Serbian raise salaries and pensions in the year of the biggest economic crisis?!), mostly stagnated the last three years, posted a real decline of about $1.5 \%$ per annum.

\section{Characteristics of the labor market and the economic crisis in Serbia}

The economic crisis has brought Serbia a far greater drop in the number of employees in relation to the drop in GDP, which led to serious social implications. The chart shows the fact that 300,000 fewer people employed for a period of eight years (2008 to 2015), and that the GDP has remained at the same level shows that the crisis affects in the first place employees and their families. An even greater decline is recorded in the socalled number of employees. Informal employment or work in the gray zone without a formal contract which does exact indicators (Zakić, 2014). However, indirectly, it can be concluded that they are employed in the informal zone are far less protected than workers employed and particularly those in the public sector. For this reason, it can be assumed that the percentage of those who are in the gray zone jobless far above the reduced number of employees in formal employment (for example 15\%. 300.000 employees). Number of employees in Serbia in the so-called. Gray zone ranges (according to most estimates, including Labor Force Survey), about half a million. So, it is very likely that during the period in the gray zone lost their jobs between 150,000 and 200,000 employees. 
Table 2. Basic sets of the population aged 15 years and over

\begin{tabular}{|c|c|c|c|c|c|c|c|c|c|}
\hline \multicolumn{10}{|c|}{${\text { Republic of Serbia }{ }^{1}}$} \\
\hline & 2006 & 2007 & 2008 & 2009 & 2010 & 2011 & 2012 & 2013 & 2014 \\
\hline \multicolumn{10}{|c|}{\begin{tabular}{|l} 
Total population age 15 and over \\
\end{tabular}} \\
\hline Total & 6512300 & 6356632 & 6350328 & 6350328 & 6317887 & 6297560 & 6277697 & 6123967 & 6098785 \\
\hline \multicolumn{10}{|c|}{ Active population, age 15 and over } \\
\hline Total & 3323716 & 3241209 & 3267107 & 3119419 & 2964966 & 2924352 & 2929481 & 2966838 & 2984408 \\
\hline \multicolumn{10}{|c|}{ Employed population, age 15 and over } \\
\hline Total & 2630691 & 2655736 & 2821724 & 2616437 & 2396244 & 2253209 & 2228343 & 2310718 & 2421270 \\
\hline \multicolumn{10}{|c|}{ Unemployed population, age 15 and over } \\
\hline Total & 693024 & 585472 & 445382 & 502982 & 568723 & 671143 & 701138 & 656120 & 563138 \\
\hline \multicolumn{10}{|c|}{ Inactive population, age 15 and over } \\
\hline Total & 3188584 & 3115423 & 3083221 & 3230909 & 3352921 & 3373209 & 3348215 & 3157129 & 3114377 \\
\hline \multicolumn{10}{|c|}{ Activity rate, $\%$} \\
\hline Total & 51.0 & 51.0 & 51.5 & 49.1 & 46.9 & 46.4 & 46.7 & 48.4 & 48.9 \\
\hline \multicolumn{10}{|c|}{ Employment rate, \% } \\
\hline Total & 40.4 & 41.8 & 44.4 & 41.2 & 37.9 & 35.8 & 35.5 & 37.7 & 39.7 \\
\hline \multicolumn{10}{|c|}{ Unemployment rate, \% } \\
\hline Total & 20.9 & 18.1 & 13.6 & 16.1 & 19.2 & 23.0 & 23.9 & 22.1 & 18.9 \\
\hline
\end{tabular}

Source: Republican bureau for statistics, 2014;

${ }^{1}$ Since 1999. No data from Kosovo and Metohia

If we look at the basic contingents in the labor market clearly we perceive a disturbing downward trend in the total population aged 15 years and will be nine years old -for almost half a million fewer people in this age category. This trend follows the active population aged 15 and over. On the other hand, the number of unemployed persons fluctuates with the ups and downs of between 450,000 and 690,000 people. The last three years saw a significant drop in the number of unemployed persons in Serbia which, in itself, does not mean that the reduced number of persons found employment in Serbia. The portion of the unemployed is discouraged reduced chances of employment left the labor market and stopped looking for work, while the other part is left Serbia and looked for a job abroad (Erokhin, 2014). Secure certificates are not jobs for the number of lower unemployment is a continuing decline in the number of employees in the entire period. The result of these trends is reflected in the rate of activity and employment, which has been constantly decreasing. The activity rate has fallen below $50 \%$, which, compared with the EU average of $70 \%$ of serious untapped potential (Table 2). 
Table 3. No of employees, age 15 and over, by sectors KD2010

\begin{tabular}{|c|c|c|c|c|c|c|}
\hline & 2010 & 2011 & 2012 & 2013 & 2014 & $\begin{array}{l}2015 / \mathrm{I} \\
\text { trimestar }\end{array}$ \\
\hline \multicolumn{7}{|c|}{ Republic of Serbia $^{1}$} \\
\hline Total & 2396244 & 2253209 & 2228343 & 2310718 & 2421270 & 2494346 \\
\hline $\begin{array}{l}\text { A - Agriculture, } \\
\text { forestry and } \\
\text { fishing }\end{array}$ & 532969 & 478111 & 467104 & 491952 & 510343 & 495660 \\
\hline $\mathrm{B}$ - Mining & 23316 & 31278 & 25844 & 22119 & 27595 & 25883 \\
\hline $\begin{array}{l}\mathrm{C}- \\
\text { Manufacturing } \\
\text { industry }\end{array}$ & 401711 & 387255 & 379614 & 394424 & 381121 & 398323 \\
\hline $\begin{array}{l}\text { D - Supplying } \\
\text { by electrical } \\
\text { energy, gas, } \\
\text { steam and } \\
\text { sewerage }\end{array}$ & 36293 & 31155 & 35377 & 37478 & 37758 & 26816 \\
\hline $\begin{array}{l}\text { E- Water } \\
\text { supplying; } \\
\text { management } \\
\text { of wastewater, } \\
\text { controlling } \\
\text { the process of } \\
\text { removing waste } \\
\text { and similar } \\
\text { activities }\end{array}$ & 41097 & 35407 & 33844 & 33651 & 37516 & 37760 \\
\hline F - Construction & 120689 & 118726 & 114853 & 109798 & 107504 & 107618 \\
\hline $\begin{array}{l}\text { G - Wholesale } \\
\text { and retail trade; } \\
\text { repair of motor } \\
\text { vehicles and } \\
\text { motorcycles }\end{array}$ & 326283 & 300600 & 302225 & 296869 & 304864 & 357183 \\
\hline $\begin{array}{l}\mathrm{H}-\text { Traffic and } \\
\text { warehousing }\end{array}$ & 125563 & 123752 & 129482 & 134431 & 130721 & 124578 \\
\hline $\begin{array}{l}\text { I- } \\
\text { accommodation } \\
\text { and food } \\
\text { servicing }\end{array}$ & 71610 & 62081 & 61528 & 58855 & 59782 & 83339 \\
\hline $\begin{array}{l}\mathrm{J}-\text { Information } \\
\text { and } \\
\text { communication }\end{array}$ & 47682 & 44387 & 33638 & 47703 & 54718 & 56018 \\
\hline $\begin{array}{l}\mathrm{K}-\text { Financial } \\
\text { and insurance } \\
\text { activities }\end{array}$ & 44852 & 43691 & 42330 & 42713 & 42022 & 48654 \\
\hline $\mathrm{L}$ - Real estate & 3268 & 3078 & 2309 & 2520 & 2788 & 4877 \\
\hline $\begin{array}{l}\text { M - } \\
\text { Professional, } \\
\text { Scientific } \\
\text { and technical } \\
\text { activity }\end{array}$ & 57053 & 54733 & 51955 & 62189 & 67027 & 57116 \\
\hline
\end{tabular}




\begin{tabular}{|c|c|c|c|c|c|c|}
\hline & 2010 & 2011 & 2012 & 2013 & 2014 & $\begin{array}{l}2015 / \mathrm{I} \\
\text { trimestar }\end{array}$ \\
\hline \multicolumn{7}{|c|}{ Republic of Serbia $^{1}$} \\
\hline $\begin{array}{l}\mathrm{N} \text { - } \\
\text { Administrative } \\
\text { and support } \\
\text { service activities }\end{array}$ & 37694 & 49079 & 49374 & 48547 & 51085 & 56866 \\
\hline $\begin{array}{l}\text { O - Public } \\
\text { administration } \\
\text { and defense; } \\
\text { compulsory } \\
\text { social insurance }\end{array}$ & 120459 & 119112 & 117786 & 131356 & 141658 & 144684 \\
\hline P - Education & 159381 & 150023 & 151452 & 149678 & 156697 & 158833 \\
\hline $\begin{array}{l}\mathrm{Q}-\text { Health and } \\
\text { social protection }\end{array}$ & 157137 & 144412 & 142041 & 130542 & 142671 & 154575 \\
\hline $\begin{array}{l}\mathrm{R}-\text { Art, fun and } \\
\text { recreation }\end{array}$ & 36964 & 26385 & 31332 & 38931 & 43693 & 50740 \\
\hline $\begin{array}{l}\mathrm{S} \text { - Other } \\
\text { service activities }\end{array}$ & 47627 & 35939 & 38836 & 46369 & 46372 & 46359 \\
\hline $\begin{array}{l}\text { T - Activities } \\
\text { of households } \\
\text { as employers; } \\
\text { activities of } \\
\text { households that } \\
\text { produce goods } \\
\text { and services for } \\
\text { own needs }\end{array}$ & 3770 & 12237 & 17223 & 29817 & 74571 & 57832 \\
\hline $\begin{array}{l}\mathrm{U} \text { - Activities of } \\
\text { extraterritorial } \\
\text { organizations } \\
\text { and bodies }\end{array}$ & 825 & 1769 & 196 & 775 & 766 & 634 \\
\hline
\end{tabular}

Source of data: Republican Bureau of Statistics

${ }^{1}$ since 1999. No data for Kosovo and Metohia

If analyzed to which activities are directed to key contingents of active persons in Serbia come to the interesting data and trends when it comes to agriculture, industry, manufacturing, construction, trade and administration? An interesting fact is certainly the number of employed in agriculture (Table 3). He is in the reporting period is around half a million employees, which is slightly above $20 \%$ of the total number of employed persons in Serbia. This percentage was significantly higher (about 27\%) in the period 2001-2010. Compared with developed countries in Europe where the number of employed in agriculture is moving mainly between 5 and $7 \%$ in the majority of countries, and rarely exceeds $10 \%$ and in traditionally agrarian countries like the Netherlands and France (except Serbia only Romania still has a high percentage employed in agriculture, which exceeds $25 \%$ of the total). The question is how Serbia such a large number of employees in agriculture. Unfortunately, this figure is not the result of expansion of our agricultural production is already one more sociological 
and social phenomenon as a result of prolonged transition of Serbian economy. This employment is compulsive and significant part a consequence of privatization in which a large number of people left without a job in large industrial centers. These are people who have been for many years, "one foot in the village and another in the city," and finally, after the transition had to turn to agriculture because for them there was no space in the failure of industrial facilities. They and their family members as unpaid members of households formed this large contingent of "employed in agriculture," not because it was their wish, but because it is for them to rest a little perspective is in other areas. This significant percentage of the number of employed in agriculture not commensurate impact on improving its efficiency (Milićević-Langović et. al., 2014). Although there are some good progress on the modernization of our production is still inefficient, fragmented landholdings, only about $2 \%$ of arable land is irrigated, we fail to renew cooperatives and organized appearance in export. Country through registration of agricultural households, the creation of an agrarian payments, various credit arrangements and modest subsidies (compared to the EU countries) made partial progress in a positive direction. It's still not enough, because the fact that we have reached only about 2 billion. Euro exports, which is 35 times smaller than the already mentioned Netherlands speaks more clearly than where we are at this moment. Good geographical position, good land and good climate are not sufficient conditions for the successful development of agriculture. It takes a lot more work on education and training of farmers, their association and rejuvenation in order to reach the desired goals (Ševarlić, 2014).

Number of employees in manufacturing, mining and, in particular, the construction industry recorded a constant decrease. Deindustrialization Serbia is almost finalized (Krstić et. al., 2013). At the same time there is a constant increase in the number and share in the structure of employment in trade, transportation, services, information technology and banking. This confirms the thesis that the twenty-first century vectors services and production to be relocated to a distant country such as China, India and others. Administration and the number of employees in state administration constantly increases by performing additional pressure and load the real sector that can hardly themselves to support. Number of employees in the public sector in Serbia (national, provincial and local administrations, public utilities, education, health, military, Interior Ministry and institutions) exceeding 600,000 employees and makes a huge burden on the budgets of the Republic and municipalities, as well as the already devastated economy. Besides this large number of people even bigger problem is their structure in terms of education, business skills and age (Mirović, Bolesnikov, 2013). For decades, the public sector are filled by incompetent cadres of the party at the expense of professional and business skills. For example, in health care is a growing number of non-medical staff at the expense of doctors and nurses in public enterprises and local governments swells unprofessional, incompetent and often corrupt administration on account of operational and manufacturing jobs. 
Table 4. Population age 15 and over,by education and activity

\begin{tabular}{|c|c|c|c|}
\hline & 2013 & 2014 & 2015/I trimestar \\
\hline & Active population & Active population & Active population \\
\hline \multicolumn{4}{|l|}{ Republic of Serbia $^{1}$} \\
\hline Total & 2966838 & 2984408 & 3088636 \\
\hline No costs & 18308 & 15672 & 9888 \\
\hline $\begin{array}{l}\text { Incomplete elementary } \\
\text { education }\end{array}$ & 136676 & 135880 & 101354 \\
\hline Elementary school & 451761 & 426142 & 416249 \\
\hline High school & 1725409 & 1731013 & 1825700 \\
\hline College & 203439 & 183727 & 197924 \\
\hline $\begin{array}{l}\text { Faculty, academy or } \\
\text { college, MSC and PHD }\end{array}$ & 431245 & 491974 & 537520 \\
\hline
\end{tabular}

Source: Republican Bureau of Statistics

${ }^{1}$ since 1999. No data for Kosovo and Metohia

If we analyze the educational structure of the active population in Serbia comes also devastating. More than half a million active population is almost functionally illiterate there is no school or have not completed primary or only primary school. It's good that this contingent from year to year, though significantly reduced. Among active residents, the largest number of those with high school and he is a little over 1.8 million citizens. In the current economic situation in Serbia, almost all of these groups are becoming difficult recruit and vulnerable (Table 4). University degree is no longer a safe ticket for the labor market, so that serious reforms are necessary both in education and training for work and towards creating better conditions for entrepreneurship, investment and economic development.

On the labor market, in addition to Serbian problems of education, training and preparedness for war and perceived vulnerability of certain categories of the population, especially in terms of their age. Big problems has young population under 35 years where he observed a large drop in the employment rate on the one hand and also jobless growth. On average today works only $55 \%$ of young people in this category while $27 \%$ are unemployed. Part of the active population aged 55 to 64 years old also from year to year is attracting a lower rate of employment (today only about $37 \%$ of the active population of this group) and an increase in unemployment (about $12 \%$ actively looking for work). Transition is both populations made vulnerable by the older crowd out of the labor market due to the collapse of many companies in the privatization and sanctions no chance of finding another job, and the younger ones are not created jobs in new companies due to a lack of investment and entrepreneurial environment that make them activated in this direction. From other vulnerable groups should be said that they improve the position of women in terms of equal access to the labor market, while the situation of Roma remains extremely difficult due to the fact that more than $50 \%$ of the working population in this population is not employed. 


\section{The legal effort to consolidate the labor market}

In response to the economic crisis in the previous period, especially immediately after the outbreak of the 2008 crisis measures to mitigate its consequences included the almost always attempts to prevent adverse effects on the labor market. Simply, the task was to preserve jobs, bearing in mind the fact that employees are the first victims of the economic crisis. The situation was similar in Serbia, where the government tried various measures to mitigate the consequences for their economies. When it comes to the preservation of jobs and the consolidation of labor market measures have gone in several directions and levels:

- General measures to stimulate the economy, which included the agreement with the IMF in 2009 worth 3 billion euros. The key aim of these measures was to support the economy through subsidized loans, loan guarantee schemes and stimulate consumption through consumer lending citizens. Support was provided to a large number of public companies and large giants such as RTB Bor and others. The condition for granting subsidized loans was to retain the same number of employees during the support. During 2009, nearly 12,000 companies have used this support and withdrew 950 million worth of loans subsidized by the state for which it is allocated 30 million euros from the budget. The government, through the Fund for Development created a program of loans for beginners in business (start-up) whose height ranged from 0.5 to 1.3 million dinars, repayment period up to 5 years, grace period of one year. In 2009 , for these purposes from the budget were spent 4 billion. RSD 2010 only about 2.2 bln., and the effect is according to the Ministry of Finance was the 9000 newly employed entrepreneurs. Apart from this program have been created programs aimed at balanced regional development and support to the economy in underdeveloped areas and devastated municipalities, through loans with interest rates of $2 \%$, a repayment period of 8 years and a grace period of 3 years. On the other hand, commercial banks were approved in 2010 about 250 million. EUR consumer loans to citizens.

- Programs designed for the unemployed are adapting measures of active employment policy (AEP) conducted by the National Employment Service (NES) possessing a modest budget of about 35 million euros. One of the most popular programs is "First Chance" is intended for youth employment to 30 years with no work experience. The state has secured the earnings for newcomers in duration from 6 to 12 months, the employer has the obligation to take over at least 12 months while maintaining the same number of employees as before the start of the program. In the period 20092011. the program reached more than 40,000 young as improved statistics of youth employment during this period. Besides the first chance at a larger scale is realized and the public works program intended for the socially disadvantaged and difficult employable categories such as older than 50 years, Roma and persons with disabilities. During 2009, this program includes about 20,000 persons and its implementation had a primarily social importance to the entire territory of Serbia. The effects in terms of permanent employment of participants in public works were left behind. In later years, the volume of funds and the number of participants is significantly reduced. 
In 2009 enacted the Law on professional rehabilitation and employment of persons with disabilities who predicted quota for employment of persons with disabilities and penalties for non-compliance of employment that are paid by employers. This law, based on positive discrimination, enabled the employment of a significant number of persons with disabilities through penalties are provided serious revenues (in 2011 almost 2 billion. Dinars) to subsidize employment of persons with disabilities. The state, in addition to these measures, through the NES and subsidize job creation, organized and financed training and retraining, which further stimulate employers to employ.

- Program increased social protection during the first years of the economic crisis were the result of a decision that social protection is the only item in the Republic budget to be increased. "Only two programs focused solely on the poor - family financial support (called MOP) and child benefit. In both programs, recorded a relative reduction before the crisis - value of child allowances decreased from $0.42 \%$ of GDP in 2005 to $0.3 \%$ of GDP in 2008, and the amount of MOP from $0.16 \%$ to $0.14 \%$. The individual level of benefits has fallen by almost half over the period from 2002 to 2008 in relation to the minimum wage. However, during the crisis, the share of social spending in GDP has increased slightly, confirming their inner potential to stabilize. However, the increase was not the result of expanding the scope of existing programs or introduce new measures. In response to the deteriorating social situation and growing poverty, the government has accelerated the process of adopting the Law on Social Protection (adopted in March 2011). " The new law provides for increase social benefits for nearly $50 \%$, but its effects are enabled poverty reduction for only a few percentage points. In 2011 the Government with employers' associations and trade unions signed a socioeconomic agreement whose objectives are directed towards supporting economic growth and increasing the competitiveness of Serbian economy while preserving the existing level of employment and macroeconomic stability (Arandarenko, 2011).

All these intentions, unfortunately, failed to stop under employment in Serbia in the period of crisis from 2008 onwards resulted in the loss of more than 300,000 jobs. The logical question is why economic and social measures in a period not to effect better economic indicators when it comes to the labor market?

There are several reasons for it and on this occasion we will look at, in our opinion, the key. When making various measures of economic policy and crisis are not recognized, the characteristics of the labor market in Serbia, primarily its duality or dichotomy. The polarization of the labor market between formal employment versus informal employment shows no signs of convergence or rapprochement, but over time creates a growing gap and the tightness of formal employment for those employees who work in so-called. Informal zone. This duality is further reflected in the relations between employment in the public sector versus the private sector, wage employment versus self-employment versus paid work and unpaid modern labor market as opposed to the traditional labor market (Ševarlić et. al., 2012). All primary, former view segments of the labor market was virtually closed for secondary segments which prevents upward mobility in the labor market. Thus, the transition from the private to the public sector, the self-employed in 
work for pay, from the informal to the formal sector is minimal and very limited.

Table 5. Dichotomy in the labor market in Serbia (2010)

\begin{tabular}{|l|r|}
\hline Public- private employment & $25: 75$ \\
\hline Formal - informal employment & $80: 20$ \\
\hline Modern - Traditional employment & $65: 35$ \\
\hline Work for pay - self-employment & $65: 25$ \\
\hline Standard - vulnerable employment & $67: 33$ \\
\hline Paid - unpaid & $92: 8$ \\
\hline $\begin{array}{c}\text { Sum is less than 100\% because it } \\
\text { excludes unpaid work Helpers }\end{array}$ & \\
\hline
\end{tabular}

Source: Republican Bureau of Statistics

Another significant reason for the relative failure of the measures is that they are primarily political character. Measures of economic policy and the labor market are targeted by certain segments of the electorate rather than segments of the labor market. When switching to a certain extent (public works, loans of the Development Fund, etc.) Would imply political arbitrariness and control in terms of who can and who can be the beneficiary and target groups of different measures. Development Fund, which is primarily directed at supporting small and medium enterprises began under various political pressures to give loans to large private companies and some failed socialist giants whose return is already in granting loans were questionable. Social measures are routed randomly and by inertia because the social map in Serbia have never done.

The third reason for the limited effect of the measures on the labor market is unfinished transition process in Serbia. Privatization is not complete, and the companies involved in the restructuring of over a hundred thousand employees who fall into the category of the most serious employable persons. Loss of a job for them, as a rule, means abandoning the labor market with no hope of finding another job. Social risks and political decisions these companies and their employees long kept out of the market, protected from coercive collection of suppliers and the taxman in a kind of anesthesia that certainly does not stop the deterioration.

The fourth group of the reasons lies in the restructuring of the public sector, inefficient and bulky state administration and the lack of ambience and infrastructure to attract investment. It is difficult to implement different economic measures aimed at attracting investment and new employment if there is no healthy economic environment and if investors at every step of trips omnipotent administration. Years of waiting for the building permit, corruption, poor road and rail infrastructure, mismanagement of 
contracts and legal uncertainty are not good recommendations nor foreign, but for domestic entrepreneurs. Part of the measures to effect and not due to the fact they were escorted precisely those parts of the administration, which previously required reform.

Serbia has so far created a large number of strategic documents and action plans for employment which, besides platitudes and principles contain specific targets, measures and policies which should lead to a serious consolidation of the labor market. As in many other areas lacking tangible results and creates the impression that the government is chaos and there is no clear policy or the will to implement it. National Employment Strategy for the period 2011-2020. was adopted by the Government provides the following strategic directions and priorities ("RS Official Gazette", No. 37/11):

- Promoting employment in less developed regions and developing regional and local employment policy,

- Enhancing human capital and greater social inclusion,

- Improving institutions and labor market development,

- Reducing the duality in the labor market.

The National Strategy envisages as a general objective of increasing employment as well as individual targets to be achieved within a given period:

- Promoting employment in less developed regions and developing regional and local employment policies,

- Improving the quality of human capital through the development of career guidance and counseling as well as increase the competences of unemployed people to acquire knowledge and skills through the establishment of a system of short training. Also, this objective implies the recognition of knowledge and skills acquired through informal learning,

- The development of institutional capacity and the expansion of the active employment policy,

- Reducing the duality in the labor market by increasing formal employment at the expense of informal, mutual respect of rights and obligations of employees and employers through a flexicurity concept and creating equal opportunities for all in the labor market.

Taking into account the seriousness and good intentions of the creators of strategic documents must be kept in mind all the circumstances and credibility entities "responsible" for the achievement of these objectives. Overlook the fact that the main actors in the realization of the National Employment Strategy to be unreformed, bureaucratized and politicized institutions in advance leads to the realization of a large number of targets. For this reason, any strategy must be based on an imperative prerequisite reformed and professionalized institutions (Mihailović et. al., 2013). Mere enactment of the reform law (any law that was passed in Serbia in the last twenty years he grew proclaimed "reform" ?!) and their implementation by the unreformed institutions closer to that old story about the new wine and old corpses. 


\section{Conclusion}

The answer to the question whether the workforce in Serbia factor of growth and development, or their limitation is not simply given, however, without any doubt is the fact that people are the greatest wealth of each country and its most important resource. This of course applies to Serbia. In our economic and social realities in recent decades that the most important resource is still only untapped potential and largely social burden the already strained state and the weakened economy. By analyzing the characteristics of the labor market in Serbia key findings indicate that it is shallow and underdeveloped, burdened by the dichotomy of "parallel worlds of work" where each have a certain lifetime jobs (public sector) and many acquired legal and customary privileges, while others on that shallow market can not even swim faced with uncertainty, insecurity and often deprived of labor rights. Serbia is still not a safe place to invest, nor was able to create a business environment to attract serious investors. Legal uncertainty, corruption, bureaucracy and politicization of all institutions are serious impediments to the free movement of capital, goods and labor in this area. Serbia's candidacy for membership in the European Union is an important and decisive step towards the establishment of a generally accepted value system in all areas, including in the field of labor.

Active working population will become an engine of development and economic growth in Serbia when multiple increase funding for the development of science and education. The result of such investments will be knowledge-based economy, where employees will have operational and usable knowledge required in the labor market. Internet and information technologies completely change the concept of education that focuses on increasing specialization and training to use different software as a tool for managing business processes. The concept of lifelong learning is no longer a matter of prestige, but a requirement for successfully performing tasks that require constant adaptation of knowledge and skills defined business objectives. In addition to investing in education, Serbia must invest heavily in the renewal of transport infrastructure, renewable energy sources (if they were able to achieve significant economic growth rate at this level of energy development, soon to face a large deficit in energy supply), stop the downward spiral of birth rate and aging population and to finally reform the public sector and administration. This would create the preconditions for the realization of all the human resources at our disposal and to come to the fore our natural talent and creativity that always expressive in circumstances of clear rules of the game. The fact that we as a nation, when it comes to sports, where rewards work, talent, perseverance and dedication, in the worst case, average, or what is more often the case, above the average of many major states, convincingly argues that we are the best when know the rules of the game (as in sports means). In our economic and social reality are not yet "clear rules", we have a weak and incomplete institutions, legal uncertainty, corruption, monopolies and centralization of the highest level. In this social messiness, we are economically inferior in comparison to others and perhaps here lies the answer to question ourselves as people often ask "why we go so bad." 


\section{Literature}

1. Arandarenko, M. (2011): Utility strategy for recovery from the crisis in South East Europe, the study estimates: Serbia, ILO.

2. Arandarenko, M., Vujic, V. (2010): “Projections of employment in the labor market in Serbia until 2020”, Quarterly Monitor no. 21, April-June, FREN, Belgrade.

3. Chmieliński, P. (2013): Labour markets for rural population: Commuting and migration abroad, Ekonomika poljoprivrede, 2013, Belgrade, Serbia, Vol. 60, No. 3, pp. 511-521, (available at: http://scindeks.ceon.rs/article.aspx?que ry $=$ ISSID $\% 26$ and $\% 2611304 \&$ page $=5 \&$ sort $=8 \&$ stype $=0 \&$ backurl $=\% 2$ fissue . aspx\%3fissue\%3d11304).

4. Erokhin, V. (2014): Approaches to sustainable rural development in a predominantly non-rural region, Ekonomika poljoprivrede, 2014, Belgrade, Serbia, Vol. 61, No. 2, pp. 291-306, (available at: http://scindeks.ceon.rs/article.as px?query $=$ ISSID $\% 26$ and $\% 2611934 \&$ page $=1 \&$ sort $=8 \&$ stype $=0 \&$ backurl $=\% 2$ fiss ue.aspx $\% 3$ fissue $\% 3 \mathrm{~d} 11934$ ).

5. http://webrzs.stat.gov.rs/WebSite/Public/PageView.aspx?pKey=1

6. Krstić, G. (2010): "The position of vulnerable groups in the labor market of Serbia," the Fund for the Advancement of Economics (FREN) and UNDP, Belgrade.

7. Krstić, S., Mihajlović, M., Dašić, M. (2013): The problem of agricultural loans in Yugoslavia between two world wars, Ekonomika poljoprivrede, Belgrade, Serbia, Vol. 60, No. 4, pp. 829-841, (available at: http://scindeks.ceon.rs/article.aspx?qu ery $=\mathrm{ISSID} \% 26$ and $\% 2611579 \&$ page $=9 \&$ sort $=8 \&$ stype $=0 \&$ backurl $=\% 2$ fissue . aspx\%3fissue\%3d11579).

8. Kuzman, B., Tešić, A., Đelić-Tanja A. (2013): Possible routes of approaching of Serbia (agro industrial complex) to the EU and the WTO, Ekonomika poljoprivrede, Belgrade, Serbia, vol. 60, iss. 3, pp. 541-549, (available at: http://scindeks.ceon.rs/ article.aspx ?query $=$ ISSID $\% 26$ and $\% 2611304 \&$ page $=7 \&$ sort $=8 \&$ stype $=0 \&$ backurl $=\% 2$ fissue.aspx $\% 3$ fissue $\% 3 \mathrm{~d} 11304$

9. Labour Force Survey, various years, Republic Institute for Statistics

10. Mihailović, B., Cvijanović, D., Paraušić, V. (2013,): Analiza performansi primarne poljoprivredneproizvodnje iprehrambene industrije Srbije, Agroznanje, Banja Luka, Republika Srpska, Vol. 14, No. 1, pp. 77-85, (available at: (https://www.google.rs/ url? $\mathrm{sa}=\mathrm{t} \& \mathrm{rct}=\mathrm{j} \& \mathrm{q}=\& \operatorname{esrc}=\mathrm{s} \&$ s ource $=\mathrm{web} \& \mathrm{~cd}=10 \& \mathrm{ved}=0 \mathrm{ahUKEwjdgv}$ TFpb3JAhWEiQ8KHUriA_cQFghRMAk\&url=http\%3 A\%2F\%2Fwww. singipedia.singidunum.ac.rs\%2Fattachment.php\%3Fattachmentid\%3D1806\%26d \%3D1295349483\&usg=AFQjCNEC5Ov6oHG_xJ6LX2xsR1JxVK2CTg\&sig2=n dv2FMVYjY-eOAHe3vOyaA

11. Milićević-Langović, A., Tomašević, V., Isaković, S. (2014): The importance of successful project team communication in agribusiness, Ekonomika poljoprivrede, Belgrade, Serbia, Vol. 61, No. 2, pp. 367-379, (available at: http://scindeks.ceon.rs/ 
article.aspx?query=ISSID $\% 26$ and $\% 2611934 \&$ page $=6 \&$ sort $=8 \&$ stype $=0 \&$ backurl $=\% 2$ fissue.aspx $\% 3$ fissue $\% 3 \mathrm{~d} 11934$

12. Mirović, V., Bolesnikov, D. (2013): Application of asset securitization in financing agriculture in Serbia, Ekonomika poljoprivrede, Belgrade, Serbia, Vol. 60, No. 3, pp. 551-564, (available at: http://scindeks.ceon.rs/article.aspx?query=ISSID $\% 26$ and $\%$ $2611304 \&$ page $=8 \&$ sort $=8 \&$ stype $=0 \&$ backurl $=\% 2$ fissue aspx $\% 3$ fissue $\% 3 \mathrm{~d} 11304$

13. National Employment Strategy for the period 2011-2020. year, "RS Official Gazette", No. 37/11

14. Republican bureau for statistics, 2014; (available at: http:/webrzs.stat.gov.rs/ WebSite/Public/PageView.aspx?pKey=1)

15. Ševarlič, M. (2014): Попис пољопривреде 2012 - значај база података о пољопривредном земљишту у Србији, (available at: https://popispoljoprivrede. stat.rs\%2F2014\%2FDokumenta\%2FRadovi\%2F01\%2520Znacaj\%2520baza $\% 2$ 520 podataka $\% 25200 \% 2520$ poljoprivrednom $\% 2520$ zemljistu $\% 2520 u \% 2520 \mathrm{RS}$. pdf\&usg=AFQjCNEyv5DGR6uijsr_PXFo828JjoIUxg\&sig2=9yyLaR6QHjCs6U UlFfIW5g).

16. Ševarlić, M., Raičević, V., Glomazić, R. (2012): Sustainable agriculture policy in support of farmers' cooperative system, Ekonomika poljoprivrede, Belgrade, Serbia, vol. 59, No. 4, pp. 633-647, (available at: http://scindeks.ceon.rs/article.as px?query=ISSID $\% 26$ and $\% 2610317$ \&page $=4 \&$ sort $=8 \&$ stype $=0 \&$ backurl $=\% 2$ fiss ue.aspx $\% 3$ fissue $\% 3 \mathrm{~d} 10317$

17. Stojadinović-Jovanović, S., Dašić, B. (2015): The importance of foreign direct investment for South East European countries' agriculture, Ekonomika poljoprivrede, Belgrade, Serbia, Vol. 62, No. 3, pp. 661-675, (available at: http:// scindeks.ceon.rs/article.aspx?query $=$ ISSID $\% 26$ and $\% 2612346 \&$ page $=5$ \&sort $=8 \&$ stype $=0 \&$ backurl $=\% 2$ fissue .aspx $\% 3$ fissue $\% 3 \mathrm{~d} 12346$ ).

18. Phan, T., Hansen, E., Price, D. (2007): A public employment service in a turbulent market, ILO Sub-regional Office for Central and Eastern Europe, Budapest.

19. Vojnović, B., Stefanović, V., Vojnović, D., Perović, M. (2014): Research on readiness for job creation through one's own agribusiness startup, Ekonomika poljoprivrede, Belgrade, Serbia, Vol. 61, No. 2, pp. 397-408, (available at: http:// scindeks.ceon.rs/article.aspx?query $=$ ISSID $\% 26$ and $\% 2612346 \&$ page $=5 \&$ sort $=8 \&$ stype $=0 \&$ backurl $=\% 2$ fissue. aspx $\% 3$ fissue $\% 3 \mathrm{~d} 12346)$.

20. Zakić, V., Kovačević, V., Ivkov, I., Mirović, V. (2014): Importance of public warehouse system for financing agribusiness sector, Ekonomika poljoprivrede, Belgrade, Serbia, Vol. 61, No. 4, pp. 929-943, (available at: http://scindeks.ceon.rs/ article.aspx?query=ISSID $\% 26$ and $\% 2612346 \&$ page $=5 \&$ sort $=8 \&$ stype $=0 \&$ backurl $=\% 2$ fissue.aspx $\% 3$ fissue $\% 3 \mathrm{~d} 12346$ ). 


\title{
ТРЖИШТЕ РАДА У СРБИЈИ - ШАНСА ИЛИ ОГРАНИЧЕЊЕ ЗА ЕКОНОМСКИ РАСТ
}

\author{
Aleksandra Tesic ${ }^{4}$, Vladimir Iic ${ }^{5}$, Anastazija Tanja Djelic ${ }^{6}$ \\ Резиме
}

Поставља се питање зашто неке државе заснивају своју економску моћ на људским ресурсима, економији знања и великим улагањима у науку, док друге своје грађане виде првенствено као социјалну категорију која изискује трошкове образовања, лечења, социјалне заштите, плата и пензија? Одговор лежи у концепту развоја друштва, односно да ли се улагање у људе сматра инвестицијом или трошком. Друштва која улагања у људске потенцијале, образовање и науку, сматрају инвестицијом су она друштва која су лидери развоја и чије економије бележе највеће стопе раста у новијој историји. Насупрот њима су друштва која још увек нису препознала значај образовања и улагања у људе као најважнији ресурс и фактор развоја. Таква друштва су на маргинама развоја, скрајнута и окупирана «унутрашњим» проблемима несвесна да је стајање у месту, у контексту економског раста, кретање уназад. Србија у овом тренутку припада, на жалост, овој другој групи држава која не схвата пуни смисао и значај људског потенцијала. Уз одређене предуслове, могуће је преокренути досадашњи концепт и формирати отворено и развијено тржиште рада које ће бити мотор развоја и кључни фактор економског раста Србије.

Кључне речи: тржиште рада, економски раст, образовање, радна места, запосленост

4 Vanredni profesor, dr Aleksandra Tesic, Fakultet za Ekonomiju i Inženjerski Menadžment u Novom Sadu, Novi Sad, Srbija, Telefon: +381 6920009 54, E-mail: prof.aleksandra.tesic@gmail.com

5 Docent, dr Vladimir Ilic, Visoka škola za poslovnu ekonomiju i preduzetništvo, Beograd, Srbija, Telefon: +381 6487877 95, E-mail: vlada191@gmail.com

6 Anastazija Tanja Djelic, Načelnik resora za poreze i akcize ministarstva finansija, Beograd, Srbija, Telefon: +381 63295 656, E-mail: tanja.djelic@gmail.com 